\title{
Effects of vitamin D supplementation and resistance training on insulin resistance, lipid profile and body fat percentage in T2D men with vitamin D deficiency.
}

\author{
Dadrass A., PhD Candidate ${ }^{1}$, Mohammadzadeh Salamat Kh., PhD ${ }^{2}$, Hamidi K., PhD ${ }^{3}$, Azizbeigi K., PhD ${ }^{4}$ \\ 1. PhD Candidate, Department of Physical Education and Sport Sciences, Sanandaj Branch, Islamic Azad University, \\ Sanandaj, Iran \\ 2. Assistant Professor, Department of Physical Education and Sport Sciences, Sanandaj Branch, Islamic Azad University, \\ Sanandaj, Iran, (Corresponding Author), Tel:+98-87-33660198, kh.mohamadzadeh@gmail.com \\ 3. Assistant Professor, Department of Biology, Mohaggeg Ardabili University, Ardabil, Iran. \\ 4. Assistant Professor, Department of Physical Education and Sport Sciences, Sanandaj Branch, Islamic Azad University, \\ Sanandaj, Iran.
}

\begin{abstract}
Background and Aim: The aim of this study was to investigate the effects of vitamin D supplementation during progressive resistance training on insulin resistance, blood lipids and body fat percentage in T2D men with vitamin D deficiency.

Methods: Forty-eight men with T2D participated in the study voluntarily and were randomly assigned to 4 groups $(\mathrm{n}=12)$ including, resistance training $(\mathrm{RT})$, vitamin D supplementation with resistance training (RT+VD), vitamin D supplementation (VD), and control groups (CON).The intervention lasted 12 weeks. VD group took $50000 \mathrm{IU}$ of vitamin D supplements every two weeks, RT group performed resistance exercise 3 times /week, RT+VD group received vitamin $\mathrm{D}$ supplements and performed resistance training, and CON group maintained normal daily life pattern. Body fat percentage, $25(\mathrm{OH}) \mathrm{D}$, blood lipids, glucose and insulin were measured before and after the intervention. HOMA-IR was used to measure insulin resistance

Results: There was a significant difference in HOMA-IR between the groups which had received vitamin $\mathrm{D}$ supplements $(\mathrm{P}<0.05)$. Furthermore, the highest reduction rate in the body weight, BMI, body fat percentage, $\mathrm{HbA1c}$, fasting glucose and insulin were observed in RT+VD group.

Conclusion: It was concluded that use of vitamin D for 12 weeks during progressive resistance training would have positive effects on insulin resistance in T2D men with vitamin D deficiency. Vitamin D supplements can be used as an effective method to reduce diabetes symptoms.
\end{abstract}

Key words: Diabetes, Resistance training, Vitamin D, Insulin resistance.

Received: Oct 11, 2017 Accepted: Feb 13, 2018 


\title{
اثر مكمل ويتامين D وتمرين مقاومتى بر مقاومت انسولين، نيمرخ لييدى خون و Dرصد جربى بلن مردان ديابتى نوع Y با كمبود ويتامين
}

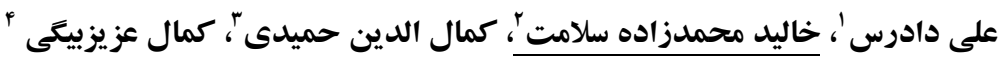

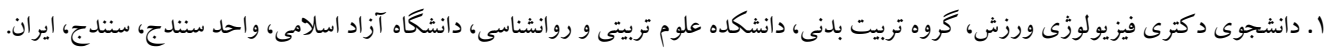

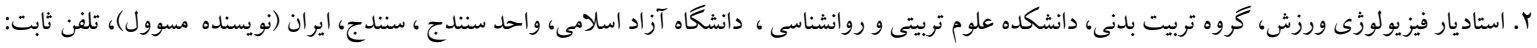

kh.mohamadzadeh@gmail.com،.1V-rr99.191

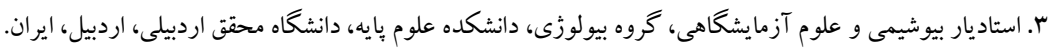

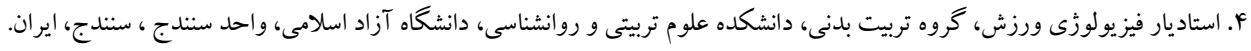

جكيuه

زمينه و هدف: هدف از يزوهش حاضر بررسى تاثير مصرف مكمل ويتامين D طى تمرين مقاومتى فزاينده بـر مقاومـت انسولين،

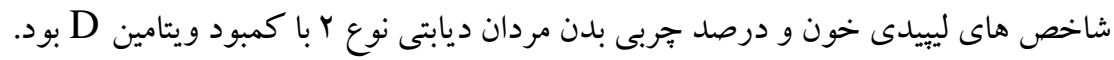

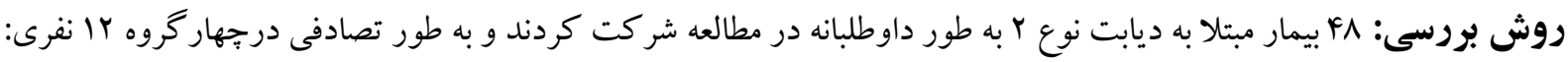

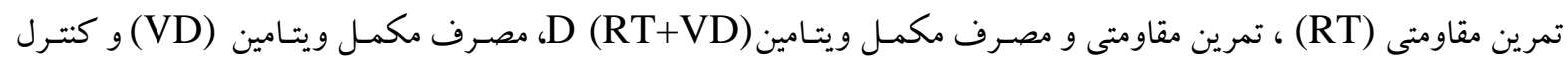

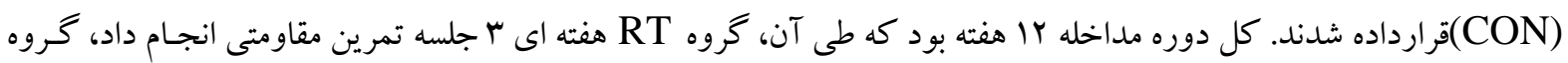

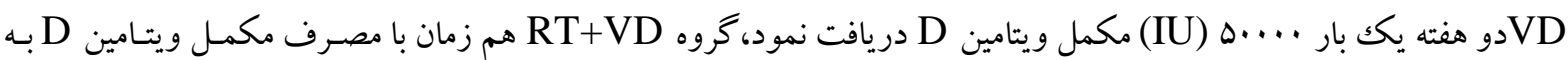

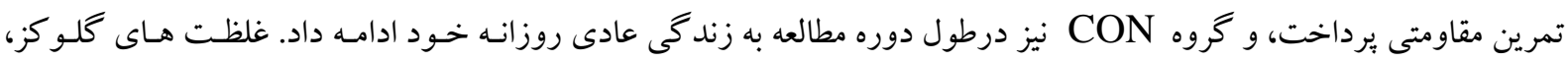

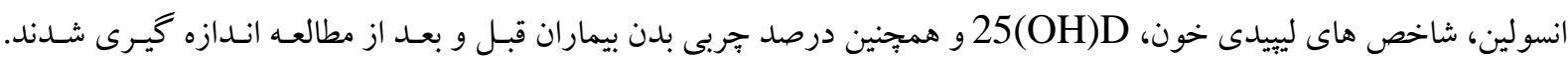

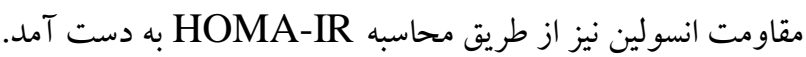

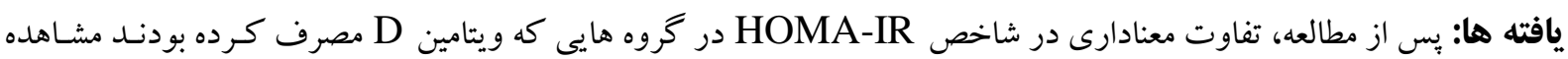

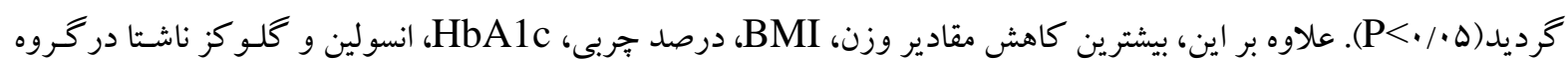
RT+VD نتيجه كيرى: نتايج تحقيق حاضر نشان داد كه مكمل سازى با ويتـامين D طسى تمرينـات مقـاومتى فز آينـده بـر مقاومـت انسولين بيمار ان ديابتى نوع r تاثير مثبتى دارد و مى تواند به عنوان يكك روش غير دارويى مـوثر در كـاهش و تخفيف علايـم ديابـت مـورد استفاده قرار گيرد. وازه كان كليدى: ديابت ، تمرين مقاومتى، ويتامين D، مقاومت انسولين

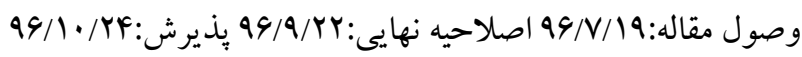


حساسيت به انسولين و هموستاز كلو كز را بـه روشسنى تاييـد

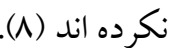

ازسوى ديخر، برخى مطالعات مربوط بـه ديابـت نشـان داده

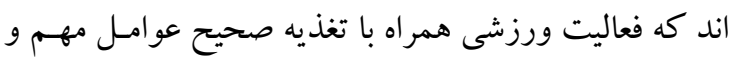

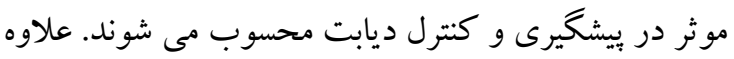
بر آن، فعاليت ورزشى منظم قدرت جسمانى افر اد ديـابتى را

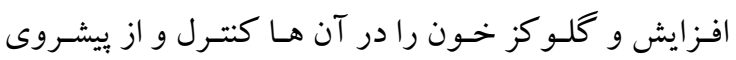

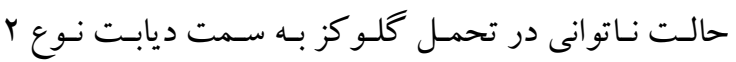

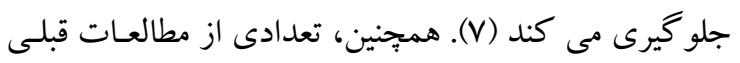
نشان داده اند كه فعاليت هاى ورزشى (هوازى، مقـاومتى يـا

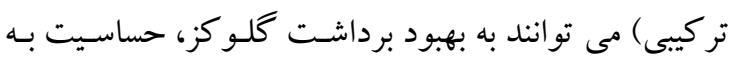

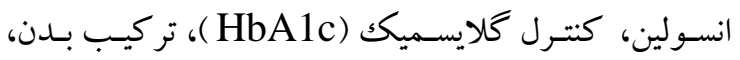

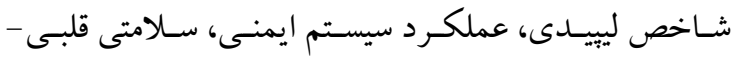
عروقى، فشار خون و توده عضلانى و استخوانى كمك كنند (9). به طور مثال، نشان داده شده است كـه تمرين مقـاومتى موجب افزايش حجم عضلات و در نتيجه افزايش ظرفيـت كلى آن ها براى مصرف كلمو كز و بهبـود هموستساز كلمو كز مى شود. با وجـود ايـن، برخى مطالعـات موفق بـه مشـاهده اثرات فعاليت ورزشى بر متابوليسم كلمو كز نشـده اند ( •(). همجِنين مطالعات انـدكى در زمينه اثر تمـرين مقـاومتى بـر بهبود وضعيت بيمارى افراد ديابتى با كمبود ويتامين D انجام شده است. يكى ديخر از اثرات تمـرين ورزشى مـنظم كاهش توده جربى بدن است بافت جربى مى تواند عوامـل التهابى ماننـد

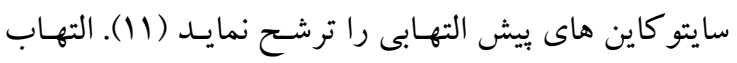

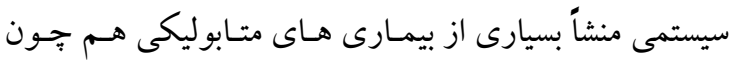

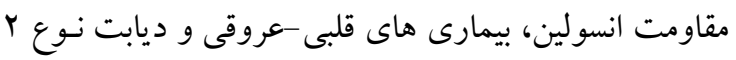

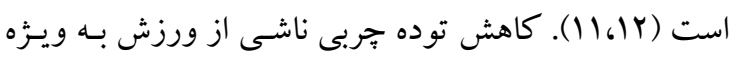

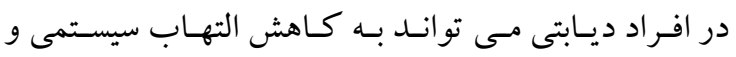

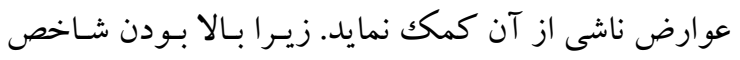

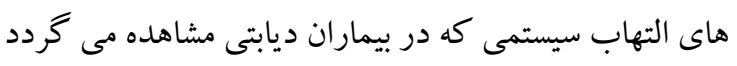

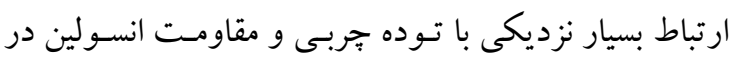

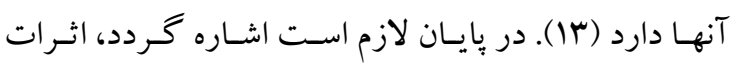

مقدمه ديابت يكك بيمارى متابوليكى است كه در اثر اختلال در عمل سلول هاى بتا پانكراس و آسيب تحمل كلوكز بروز

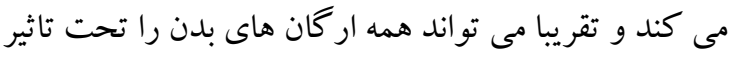

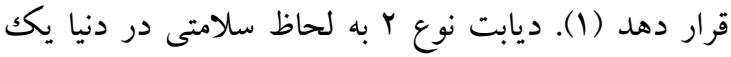
مشكل جدى و مهم به شمارمى رود و به صورت إيدميك و

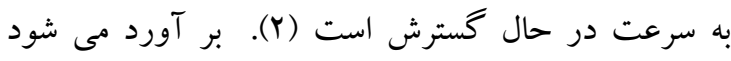

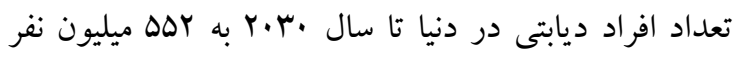

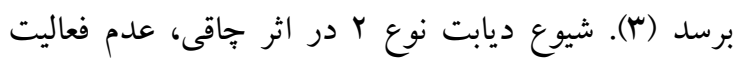

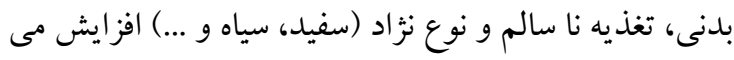
يابد (F). تاثير اقتصادى ديابت بسيار زياد است و هزينه

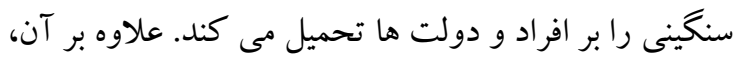
افر اد ديابتى درمعرض مشكلات و عوارض متعددى از قبيل بيمارى هاى قلبى و عروقى، سكته مغزى، نارسايى كليوى،

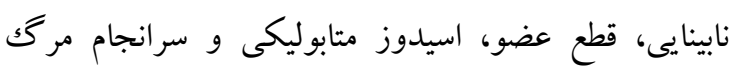
زودرس قراردارند (ه). اغلب، اين عوارض در اثر بالا بودن ميزان قند خون ناشى از ديابت كنترل نشده به وجود مى

همانند ديابت نوع r، اختلال ديخرى كه در دنيا بسيار شايع است كمبود ويتامين D مى باشد. اين كمبود ممكـن است ناشى از عدم استفاده كافى از نور خورشيد، افزايش جاقى، عدم استفاده از غذاهاى حاوى ويتامين D مثل ماهى، قارج ؛ و نيز افزايش سـن باشـــ. نشـان داده شـــه اسـت كـه كمبـود ويتامين D Dى توانـد موجـب افز ايش مقاومـت انسولين و بروز ديابـت نـوع r شـود (9). بنـابر اين درسـال هـاى اخيـر، ويتامين D به عنوان يك عامل مهم در بهبود بيمارى ديابـت و عـوارض ناشسى از آن مطـرح شـده اسـت (V). همجنـين، گز ارش شده است كه بالارفتن غلظت ويتامين D در خـون، از راه افزايش حساسيت به انسولين، به حفظ هموستاز كلوكز كمكك مى كند و ممكن است ترشح انسولين را توسط سلول هاى بتا پانكراس تحريك نمايد و در نتيجه، تحمل گكلو كز را

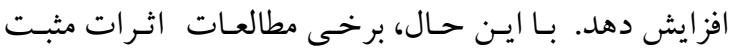
استفاده از مكمل ويتامين D بر شـاخص هـاى كلايسـميك، تركي. 


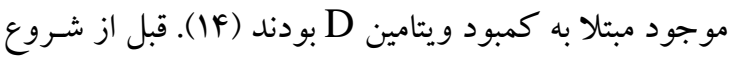

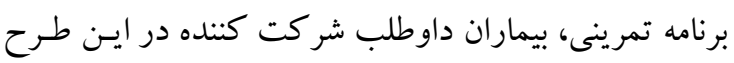

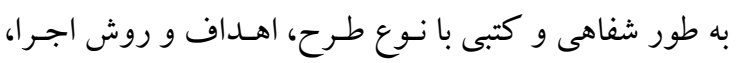

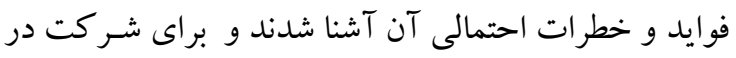

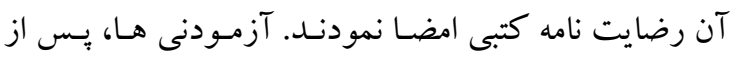

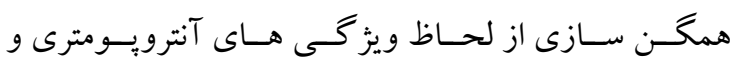

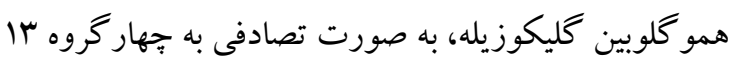

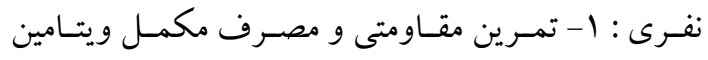
r (RT+VD ) D

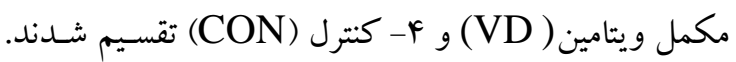

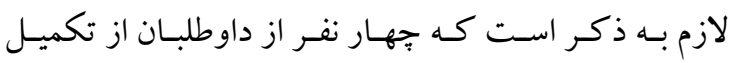

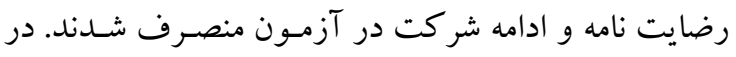
هر كروه rا انفر تا بايان طرح باقى ماندند. تمـامى برنامـه هـا

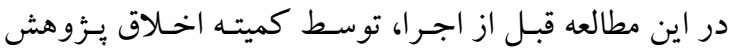

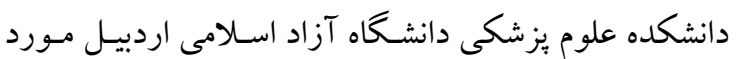

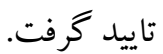
اندازه گيرى هاى آنترويومتريكك: در ابتدا، افراد مـورد مطالعـه در پيايخحاه قهرمـانى اداره كـل ورزش و جوانـان اسـتان اردبيـل حضـور يافتنـــ. بـه منظـور كاهش اثرات يـاد گيرى، طلى جنــد جلسه بـا نحسوه انجـام

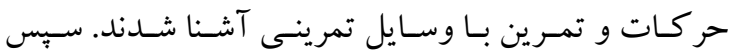
دريايكاه استعداد يابى ورزشى آن اداره انـدازه گيـرى هـاى نهاى

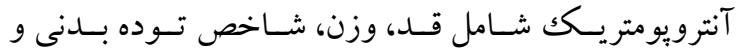
درصدجربى بدن انجـام گرفـت. همجنـين، حـداكثر قـدرت براى حر كات مورد نظر در تحقيق تعيين گرديد. براى تعيين حداكثر قدرت، مقدار جابه جايى يكك وزنه زيربيشينه تا حد خستكى ثبت شده و با استفاده از فرمول يكك تكراربيشـينه

$$
\text { (1RM) }
$$

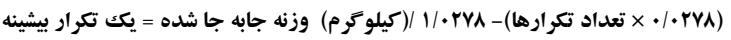
شاخص توده بدنى(BMI) بيماران نيز با استفاده از فرمول وزن بدن (بر حسب kg) تقسم بر مجذور قد (بر حسب متر)

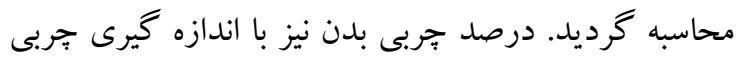
زير يوستى توسط كاليير (مدل هاريندِن ساخت شركت
تمرين ورزشى بر متابوليسم كلو كز در افراد ديابتى هنسوز بـهـ روشنى مشخص نيست. برا اسـاس اطلاعـات مـا تـاكنون اثر

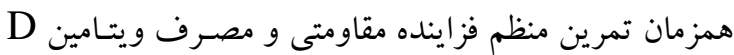

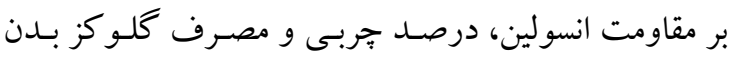

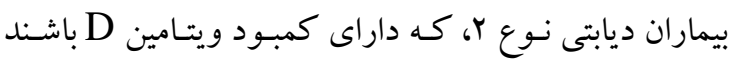
مورد بررسى قرار نخرفته است. همجنين بيشتر مطالعات انجام شده در اين زمينه اثرات تمرين استقامتى و هوازى را بررسى ترسى

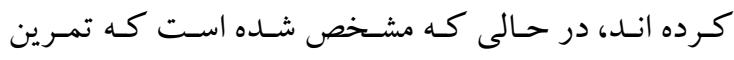

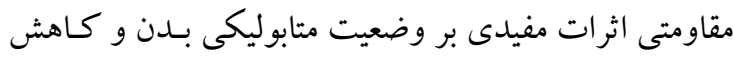

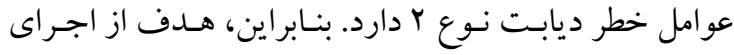
تحقيق حاضر بررسى بيشتر اثرات مكمل ويتامين D و تمرين

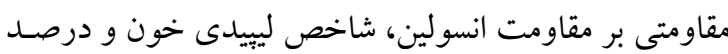
جربى بدن در مردان ديابتى نوع Y با كمبود ويتامين D بود.

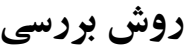
نوع تحقيق و آزمودنى ها:

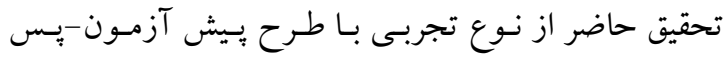

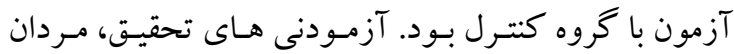

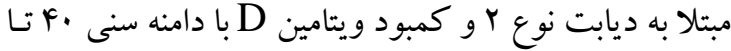

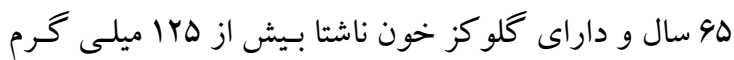
بر دسى ليتر بودند كه به كلينيك ديابت شهر اردبيل مراجعه مى كردند. در اين مطالعه براساس معيارهاى ورود به مطالعه،

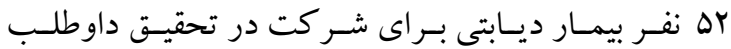
شدند(V). معيارهاى ورود به مطالعه شـامل تمايـل بيمـار بـهـ شركت در مطالعه، فقـدان نارسـايى هـاى كبـدى و كليـوى، بيمارى هاى قلبى -عروقى، استخوانى، نداشـتن فشـار خـون

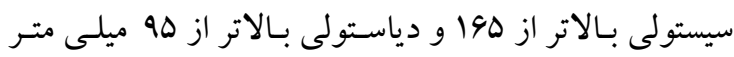
جيوه، نداشتن سابقه فعاليت ورزشى و عدم مصرف ولـ ويتامين

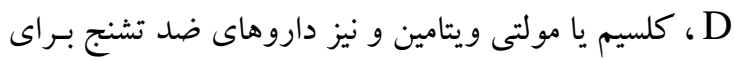

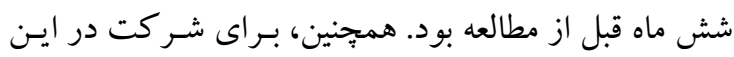

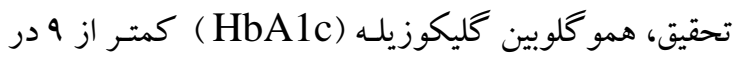

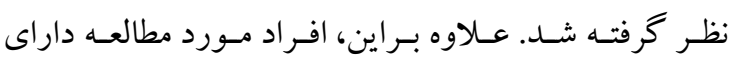

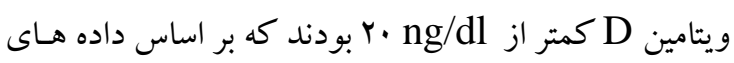




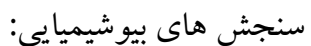
از افراد شركت كننده خواسته شد در روزهاى قبل از خونگيرى، رزيم غذايى مشابه داشته باشند تا حتى الامكان اثرات تغذيه ایى بر سنجش هاى بيوشيميايى به حداقل برسد.

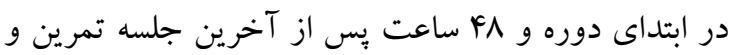

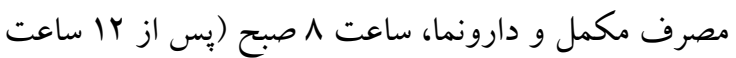

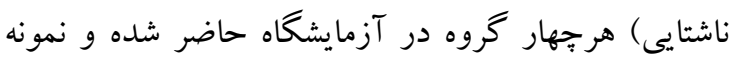
هاى خونى درحالت نشسته روى صندلى به ميزان · ل ميلى

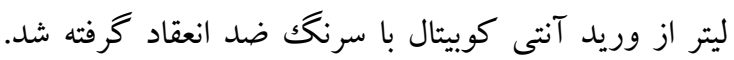
سبس نمونه هاى خونى به لوله هاى مخصوص منتقل شده و

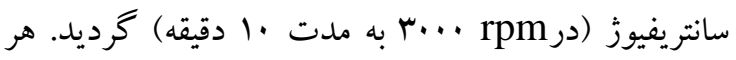

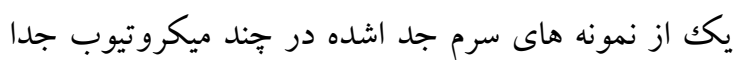
ريخته شده و در دماى •^- درجه سانتيخراد تا زمان اندازه كيرى فريز شدند. غلظت هاى سرمى انسولين با استفاده از كيت هاى الايزا

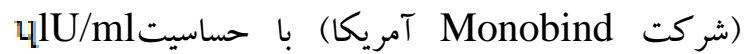

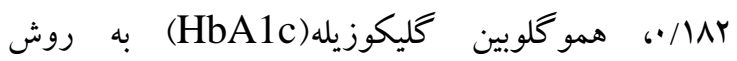
كروماتو گرافى تعويض يونى و با استفاده از كيت هاى هوين مخصوص (شركت Biosystem اسيانيا)، غلظت 25(OH)D3 با استفاده از كيت هاى Elisa (شركت ng/ml آلمان) با حساسيت Bioactiva diagnostica 19V •، غلظت كلو كز ناشتا با استفاده از كيت كلو كزاكسيداز

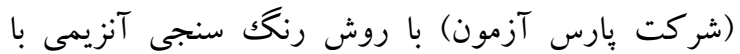
حساسيت mg/dl ه، اندازه گيرى شدند. براى اندازه گيرى مقاومت انسولين از روش مدل هموستاز طبق فرمول زير

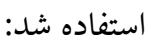

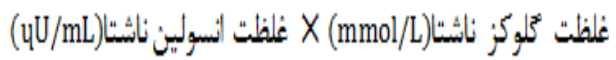
HOMA $-I R=\frac{}{22 / 5}$

TG-، HDL-C, هم جنين اندازه گيرى هاى كلسترول تام LDL-C و با استفاده ازكيت هاى شركت بِارس آزمون به روش اسبكتروفتومترى آنزيمى انجام گرفت.

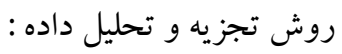

Baty انگلستان) درسه ناحيه سينه، شكم وران گرفته شده و با استفاده از معادله جكسون ويولاكك محاسبه شد (ها).

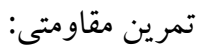
افراد مورد مطالعه در ابتداى هرجلسه تمرينى ها دقيقه بدن

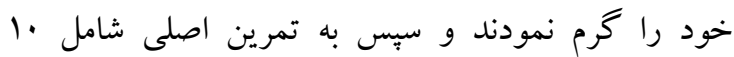

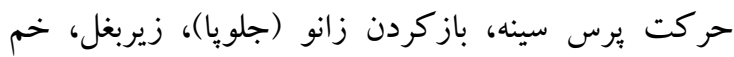

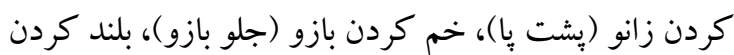
پِاشنه (روى ينجه)، شناى سوئدى تعديل شده (زانو روى

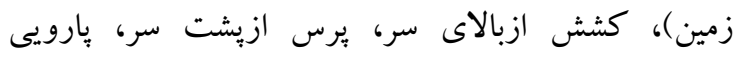

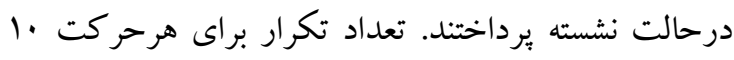

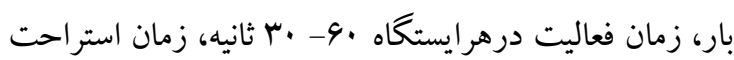

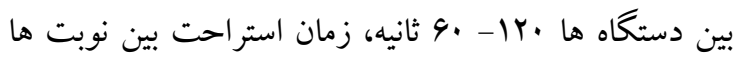

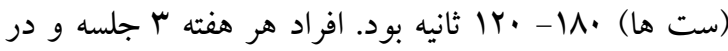
هرجلسه ץ نوبت (ست) تمرين كردند. شدت تمرين هاتهر درصد يكك بار بيشينه در F هفته اول؛ هذ9 درصد درץ هفته دوم؛ VD درصد درF هفته سوم بود. افزايش مقدار وزنه،

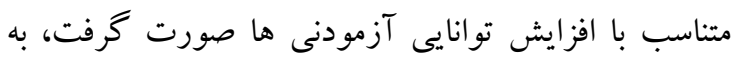
همين دليل حداكثر قدرت (1RM) آزمودنى ها در هر

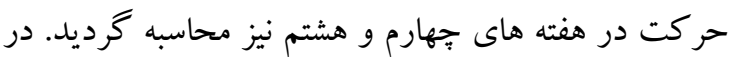
بإيان هرجلسه تمرينى آزمودنى ها به مدت ·ل دقيقه به سرد كردن بدن برداختند

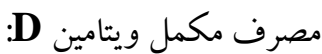
به منظور ارزيابى دقيق اثر مصرف ويتامين D، اين مكمل با استفاده از روش دو سو كور توزيع گرديد. افراد دو گرووه RT و Rو هفته يكك بار ل.... RD واحد بين الملى (IU) مكمل ويتامين D (ساخت شركت داروسازى زهراوى- ايران) به صورت كيسول به مدت آلهفته مصرف

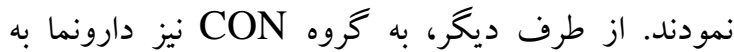
صورت كيسول هاى حاوى بارافين خوراكى (ساخت همان

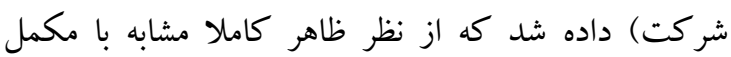
ويتامين D بود. افراد درطول مطالعه، رزيم غذايى معمول خود را ييروى نموده و از مصرف مكمل هاى ديخر خودارى نمودند. 
معنادار كلسترول در گروه هاى RT+VD و RT بود. به

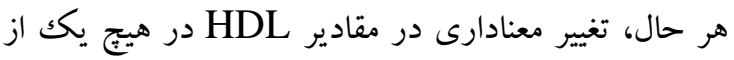

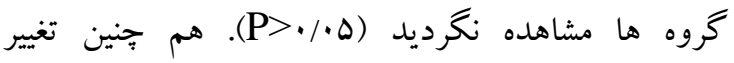
معنادارى در هيج يكك از متغير هاى مربوط به شاخص ليييدى هردي

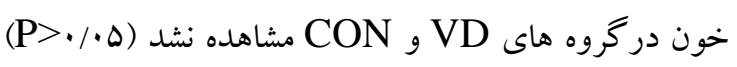

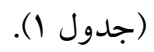

:25(OH)D و HbA1c

هر جند تفاوت هاى بين گروهى معنا دارى در مورد 25(OH)D , HbA1c

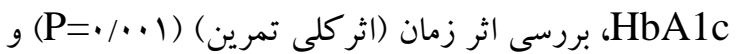

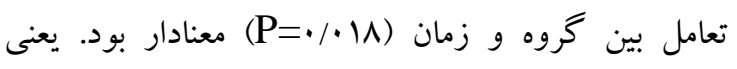
تمرين مقاومتى و مصرف ويتامين D موجب كاهش معنادار

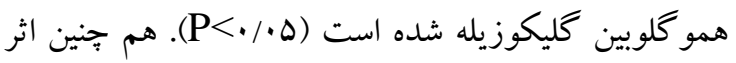

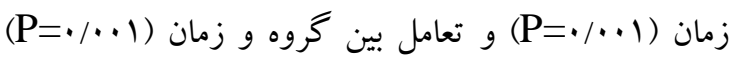

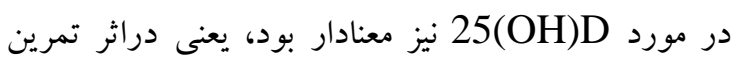
مقاومتى و مصرف مكمل ويتامين D مقادير

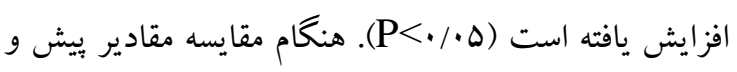

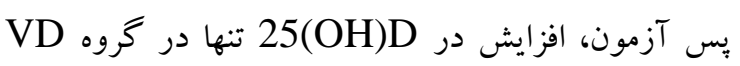

معنادار بود (جدول ()).

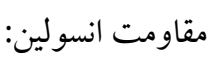

نتايج آزمون تحليل واريانس دو راهه با اندازه گيرى هاى

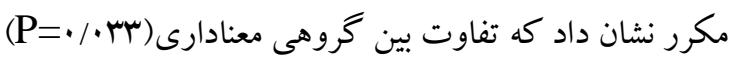
در مورد HOMA-IR وجود دارد. همجِنين اثر زمان

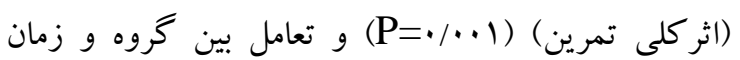

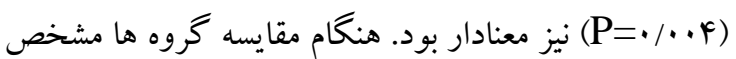
شد گروه هاى RT+VD و RD نسبت به كروه كنترل تفاوت معنادارى داشتند. در مورد انسولين ناشتا نيز، اثرزمان (P=•/・1) آمارى معنادار بود. بررسى ميانگين ها نشان داد كه تمرين مقاومتى و مصرف ويتامين D موجب كاهش انسولين شده

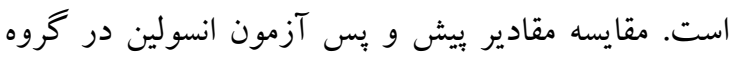
هاى RT+VD و RT حاكى از كاهش معنادار آن بوده
ابتدا توزيع طبيعى داده ها با استفاده از آزمون كلمو گروف - اسميرنوف و همخنى واريانس ها با استفاده از آزمون لِون انون

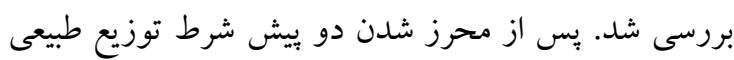

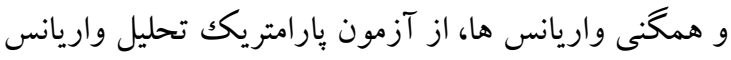

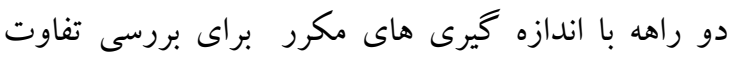

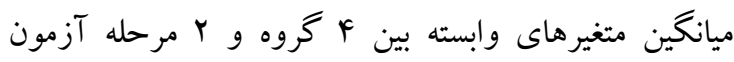

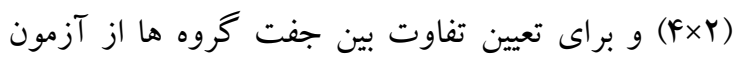

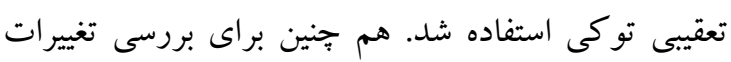

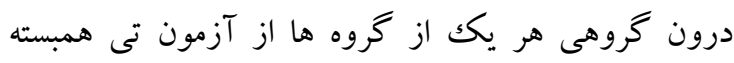

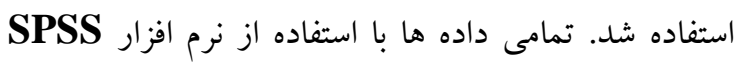
نسخه إ درسطح معنادارى ه •/ • مورد تجزيه وتحليل قرار كرفتند.

\section{يافته ها} شاخص هاى آنترويومتريك: در تحليل درصد جربى بدن، اثر زمان (اثر كلى تمرين) از

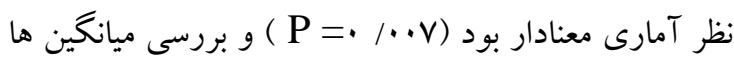
نشان داد درصد جربى بدن در اثر تمرين مقاومتى و مصرف

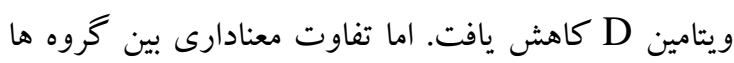

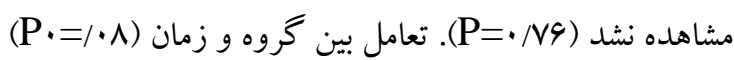
نيز معنادار نبود. هم جَنين، كاهش معنادارى در BMI و

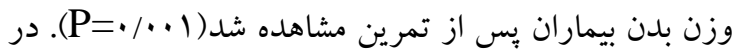

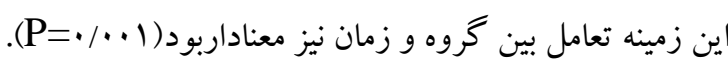
در اين مورد بيشترين كاهش در گروه هاى RT+VD RT,

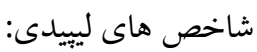
در مورد شاخص هاى ليييدى خون، تمرين مقاومتى و

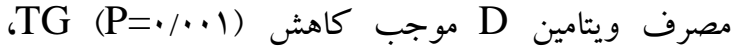
و و كلسترول(PDL (P=・/・1) تعامل بين گروه و زمان (اثر كلى تمرين) در مورد (P=.02)TG

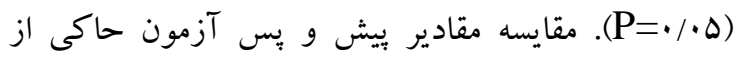

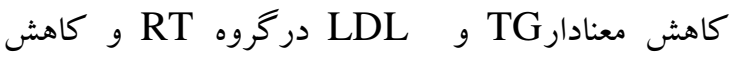


4 اثر مكمل ويتاهين D و تمرين...

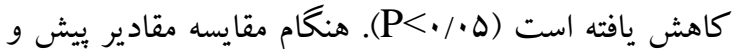
بس آزمون تغيير در گلوكز تنها در گروه RT+VD معنادار

$$
\text { بود (جدول ()). }
$$

است. در زمينه كلوكز خون ناشتا نيز اثر زمان ( (P= (P) و

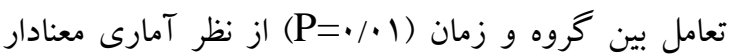
بودند. يعنى بررسى ميانگين ها نشان داد كه در اثر تمرين مقاومتى و مصرف ويتامين D مقادير كلوكز خون ناشتا

جدول ا. ويز گى هاى فيزيولوزيكى، عوامل مقاومت انسولين و شاخص هاى ليييدى افراد قبل و پِس از مكمل سازى و تمرين مقاومتى، داده ها به صورت MESD

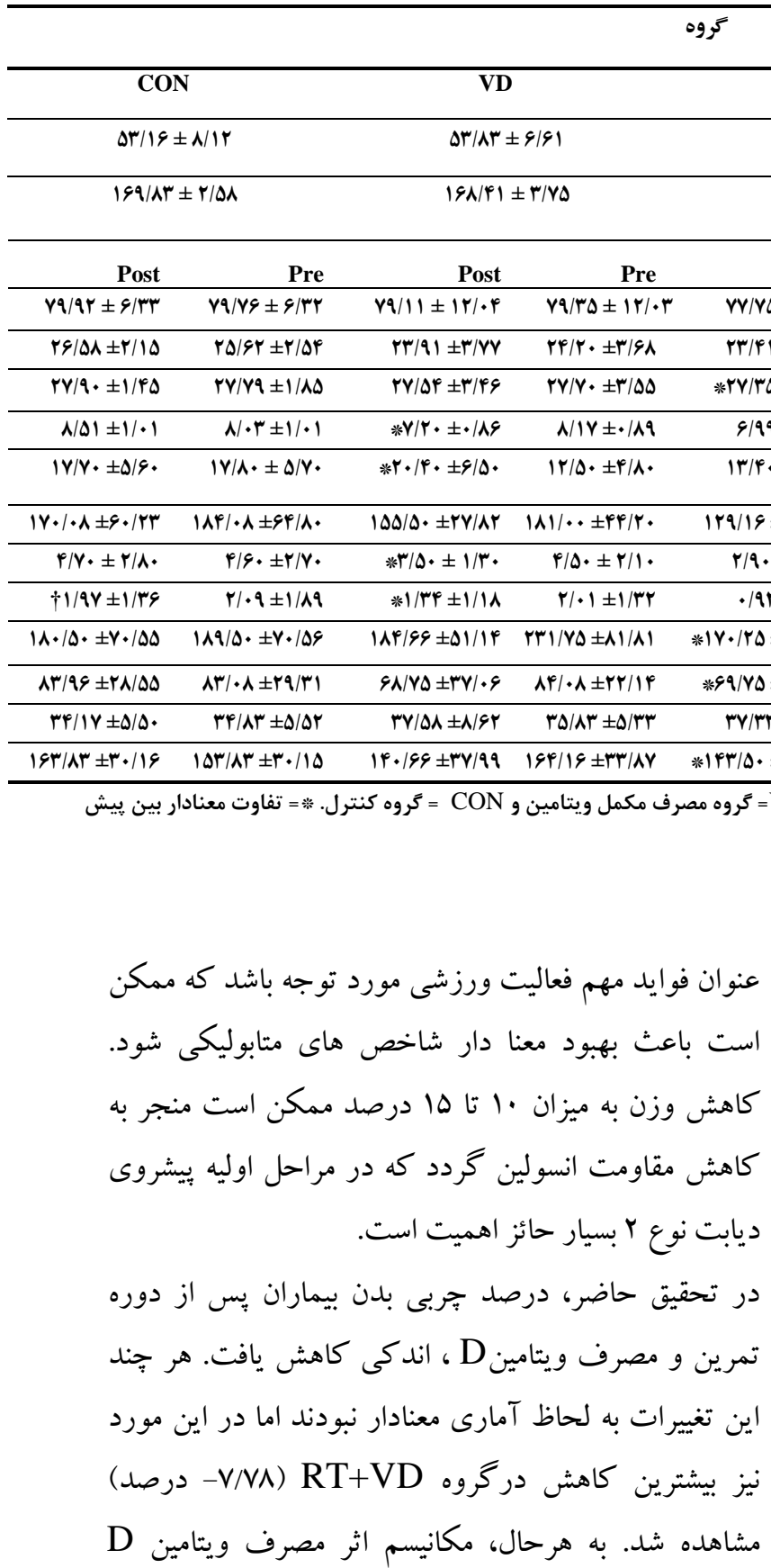

\begin{tabular}{|c|c|c|}
\hline RT & RT+VD & متغير \\
\hline$\Delta \varphi / q) \pm \Delta / \wedge \varphi$ & $\Delta \Gamma / \mathrm{V} \Delta \pm \mathrm{N} / \cdot \cdot \cdot$ & سن (yr) \\
\hline
\end{tabular}

$\begin{array}{rrrr}\text { Post } & \text { Pre } & \text { Post } & \text { Pre }\end{array}$

$\begin{array}{cccc} & \text { Pre } & \text { Post } & \text { Pre } \\ \text { P } & \text { P }(\mathbf{k g})\end{array}$


كلو كز ناشتا و HbA1c مى شود. در حالى كه، در مطالعه

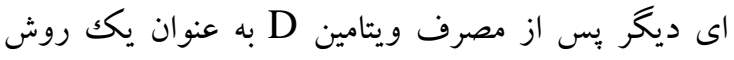

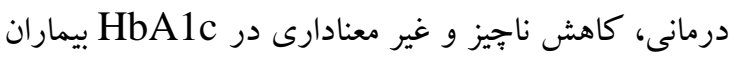

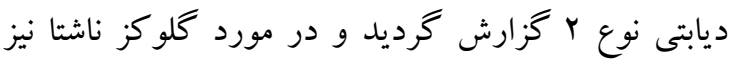

هيج تفاوتى نشان داده نشد (19).

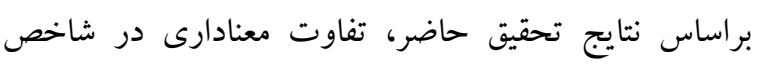

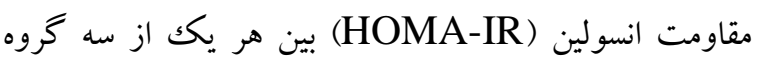

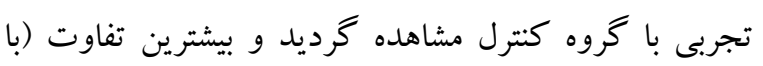

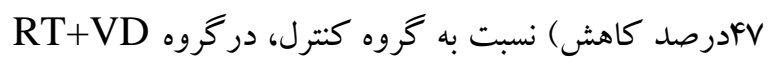

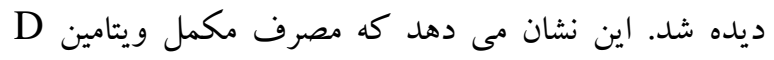
همراه با تمرين مقاومتى در كاهش مقاومت انسولين موثر بوده

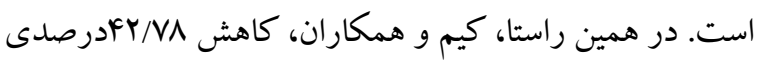
شاخص مقاومت انسولين را در گروه مصرف ويتامين D همراه با تمرينات ورزشى، در مقايسه هر يكك به تنهايى، مشاهده

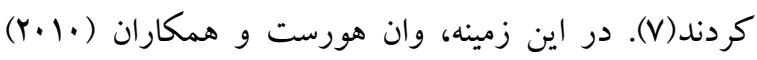

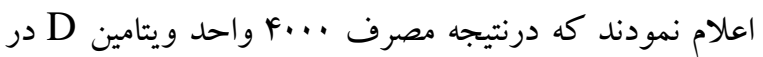

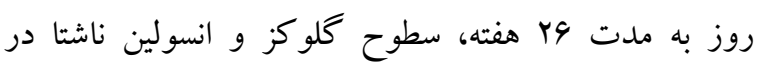
بيماران ديابتى به طورمعنادارى كاهش يافت (·r). جنين

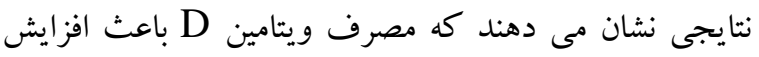
توليد و حساسيت به انسولين مى شود و بر حفظ هموستاز كلو كز تاثير مى كذارد. محققان بر اين باورند كه فعاليت ورزشى منظم، موثرترين

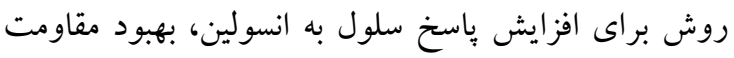

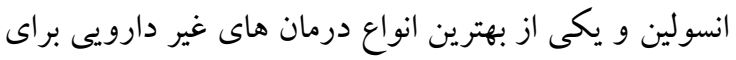
بيشخيرى و كنترل ديابت محسوب مى شود. همجنين، نشان داده شده است كه تمرين مقاومتى فزاينده، همانند تمرينات

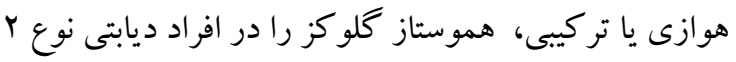
بهبود مى بخشد و نيز از كاهش توده غير جربى بدن

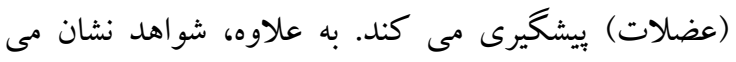

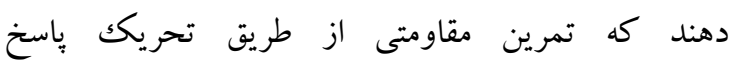
هيبرتروفيك و تغيير نوع تارهاى عضلانى، باعث افزايش

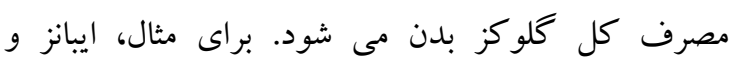

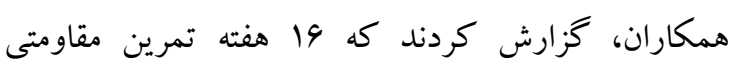

برتركيب بدن به روشنى مشخص نيست. با اين حال نشان داده شده است كه توده جربى بدن محل اصلى بروز التهاب

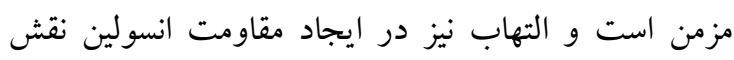

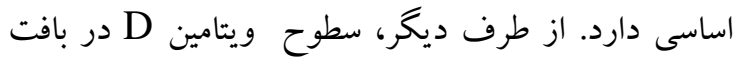
جربى عامل تعيين كننده و تاثير گذار در فر آيند التهاب به وديه شمار مى رود. نقش ويتامين D در تعديل التهاب از طريق تاثير آن بر ايمنى ذاتى و قابل تغيير بدن و نفوذ آن بر فعاليت سلول هاى ارايه كننده آنتى زن، ترشح سايتو كاين ها و و

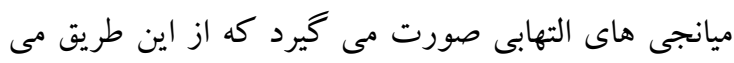

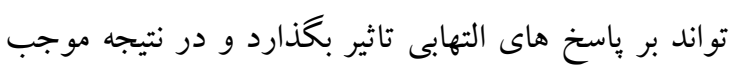

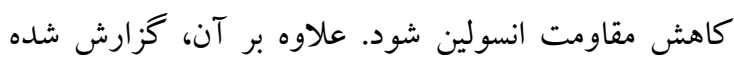

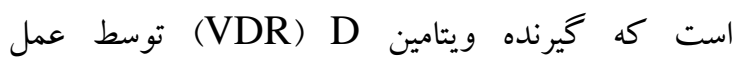

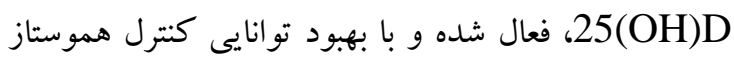
كلسيم تاثير مثبتى بر تركيب بدن مى كذارد (19). در تحقيق

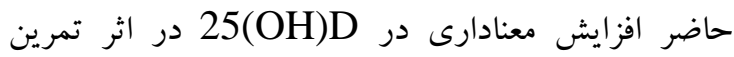
مقاومتى و مصرف مكمل ويتامين D خصوصا درگروه ويتامين D (با Y/T د درصد)؛ و همجنين كاهش معنادارى در

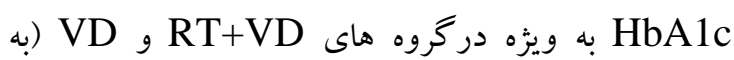
ترتيب r|- و ||- درصد) مشاهده گرديد. اين نتيجه نشان مى دهد كه تمرين مقاومتى همراه با مصرف مكمل ويتامين

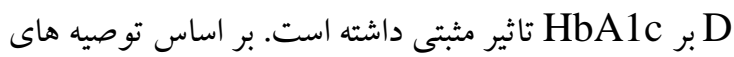

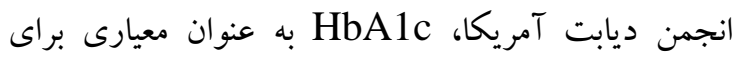
تشخيص ديابت يذيرفته شده است و به عنوان يك معيار

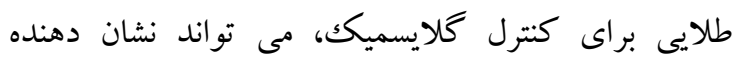
عوارض ناشى از ديابت باشد. از طرف ديخر، در مطالعات

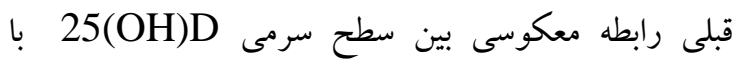

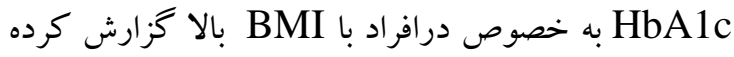

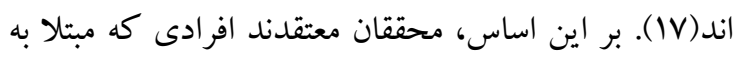

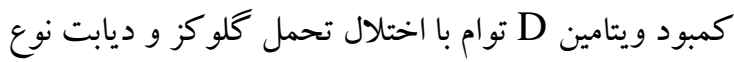
r هستند، تجويز ويتامين D ممكن است باعث بهبود ترشح انسولين و تحمل كلو كز و كاهش همسو با آن، مطالعه اى نشان داده است مصرف وف مكمل

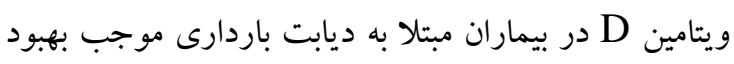


گيرنده هسته اى موجود در زن سنتز كننده گيرنده هاى

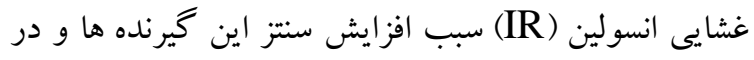
نتيجه حضور GLUT-4 وابسته به انسولين در غشاء سلولى أنى

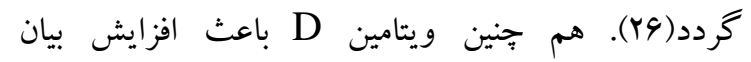

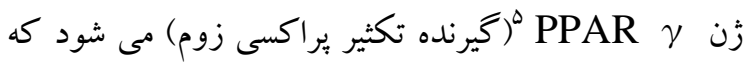

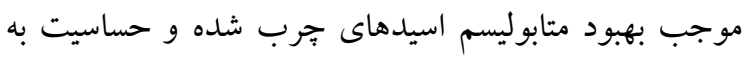
انسولين را افزايش مى دهد(YV). به علاوه، نشان داده شده است كه ويتامين D از طريق كاهش بيان زن رهن رنين و نيز مهار

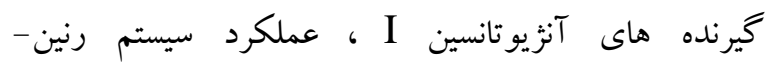
آنزيوناسينوزن را تعديل مى كند. افزايش فعاليت اين سيستم

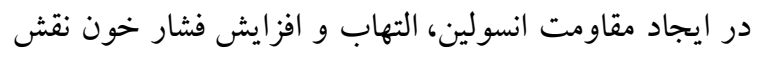

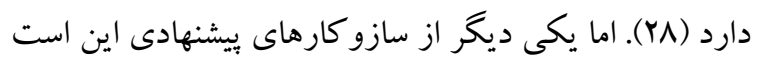

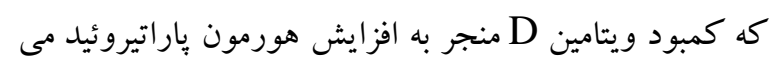
شود كه افزايش آن با لييوزنز، جاقى و مقاومت به انسولين مرتبط است. افزايش هورمون باراتيروئيد موجب افزايش درون سلولى مى شود. افزايش $\mathrm{Ca}^{++}$

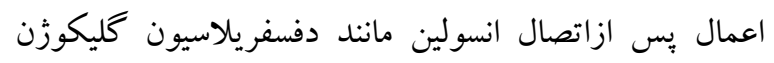

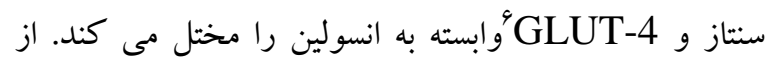

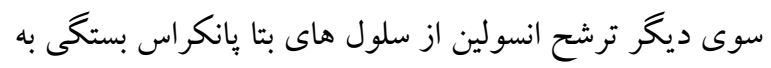

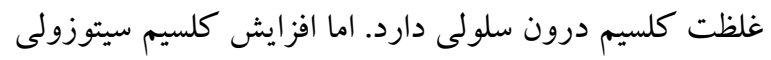

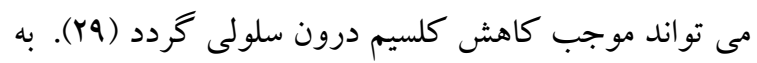

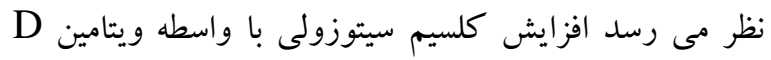
در بافت هاى عضلانى مسئول افزايش انتقال كلوكز به عضله باشد. همجنين، ويتامين D گيرنده هاى هسته اى محيطى را

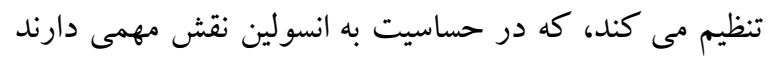

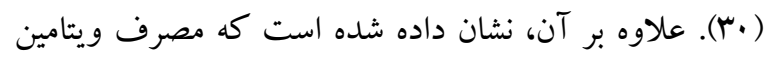

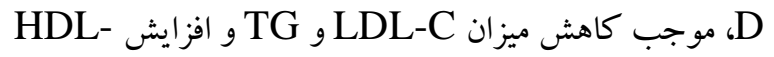
C

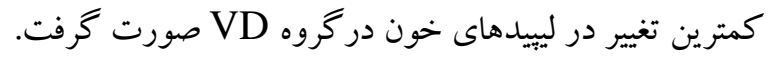
پاسخ لييدهاى خون به تمرين ورزشى در مطالعات گوناكون،

\footnotetext{
5 - peroxisome proliferator-activated receptor d gene ${ }^{6}$ - Glucose transporter-4
}

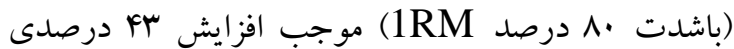
عمل انسولين و كاهش V/I درصدى سطح كلوكز بلاسما

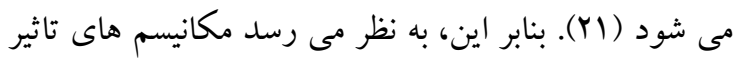

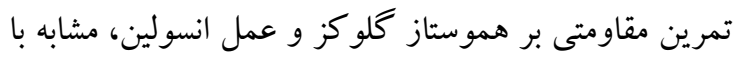

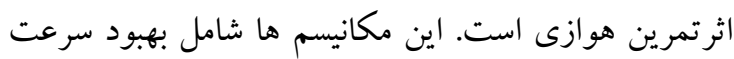

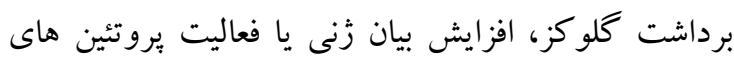

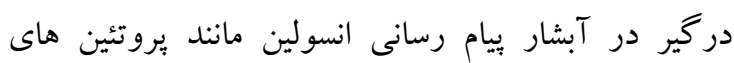
Akt يا PI3K ، 'PRS-1

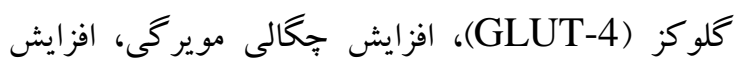

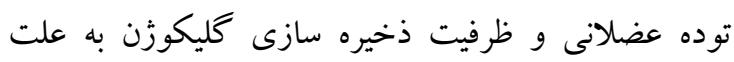
افزايش فعاليت آنزيم كليكوزن سنتاز مى باشند (YY-YY) توجه نتايج فوق، نشان داده شده است كه تمرين مقاومتى

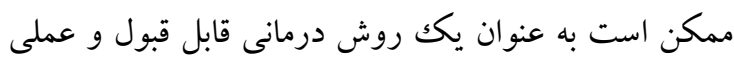

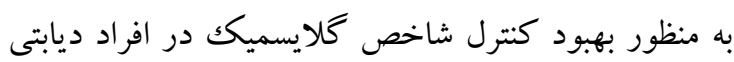

سالخورده، با شدت متوسط و سرعت كم، تجويز گردد. در تحقيق حاضر بررسى ميانگين ها نشان داد كه مقادير

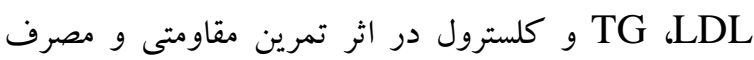
ويتامين D كاهش و ميزان HDL افزايش يافته است. هر جِند

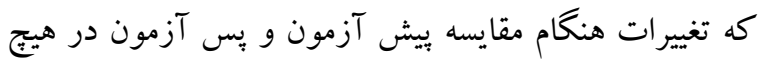
يكك از متغيرهاى نيمرخ ليييدى معنادار نبود، اما بيشترين تغيير درگروه تمرين مقاومتى (RT) مشاهده شد. كيم و همكاران

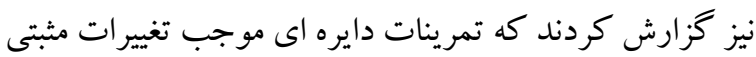

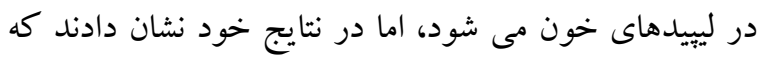
اثرات تركيبى مصرف ويتامين D و تمرينات ورزشى بر ليييدهاى خون، مقاومت انسولين و تركيب بدن بيشتر از مداخله انفرادى است(V). در اين راستا، گزارش شده است كه

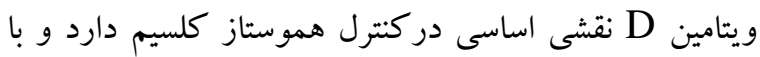

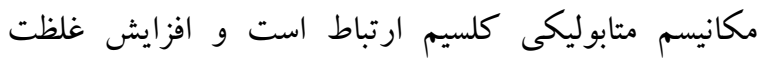

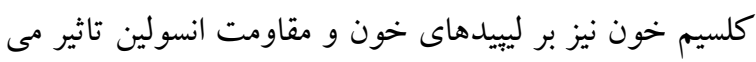
كذارد (Y) (Y). 1,25(OH)2D3

\footnotetext{
1 - Insulin Substrate-1

2 - phosphoinositide- 3 kinase

3 - protein kinase B

4- 1,25-dihydroxyvitamin D3
} 


$$
\begin{aligned}
& \text { دارد. خصوصا، نتيجه مهمى كه از تحقيق حاضر به دست آمد، } \\
& \text { اين است كه هر زمان مصرف مكمل ويتامين D با تمرينات } \\
& \text { ورزشى توام مى شود، بهبود بيشترى درشاخص مقاومت } \\
& \text { انسولين و HbA1c حاصل مى گردد. }
\end{aligned}
$$

$$
\begin{aligned}
& \text { تشكر و قدردانى } \\
& \text { از معاونت يُزوهشى و دانشكده علوم يزشكى دورد دانشگاه آزاد }
\end{aligned}
$$

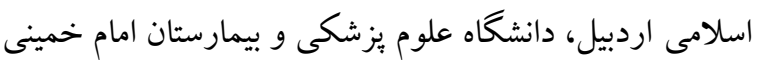

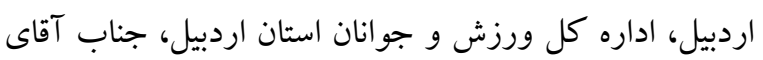

$$
\begin{aligned}
& \text { دكتر محمد ضعيفى زاده، جناب آقاى دكتر احد جعفرى، }
\end{aligned}
$$

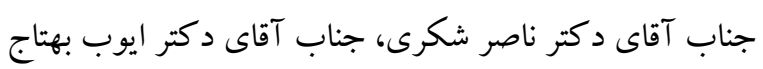

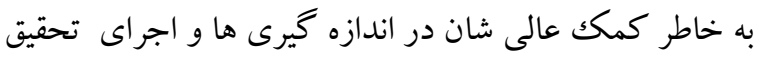

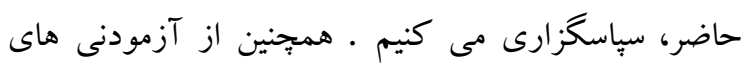

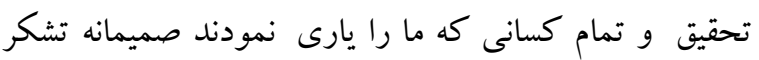

$$
\begin{aligned}
& \text { و قدردانى مى نمائيم. }
\end{aligned}
$$

متفاوت است و بيشتر اين مطالعات كاهش اندك LDL-C

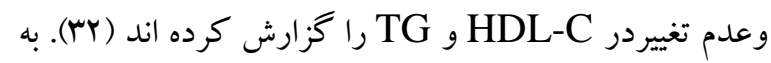
نظر مى رسد علت عدم تغيير معنادار ليييدهاى خون در برخى تريردي

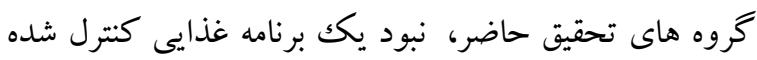
است. اشاره شده است كه كنترل دقيق برنامه غذايى روزانه بيماران مى تواند در ميزان لييدهاى خون تاثير بكذارد (V).

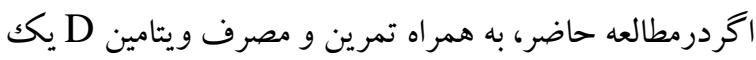
برنامه محدوديت كالرى دريافتى به بيماران تجويز مى شد، هردئ شايد اثرات كاهشى بيشترى در شاخص هاى ليبيدى اين بيماران مشاهده مى خرديد. نتيجه كيرى نتايج اين مطالعه نشان داد كه مصرف مكمل ويتامين D و تمرين مقاومتى به مدت Ir هفته، تاثير مثبتى بر شاخص هن

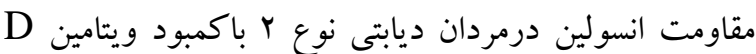

\section{References}

1. Seshadri KG, Tamilselvan B, Rajendran A. Role of vitamin D in diabetes. J Clin Endocrinol Metab 2011; 12: 47-56.

2. Ramachandran A, Snehalatha C, Ma RC. Diabetes in south- East Asia: An update for 2013 for the IDF Diabetes Atlas. Diabetes Res Clin Pract 2014; 103: 231-7.

3. Unwin N, Whiting D, Guariguata L, Ghyoot G, Gan D. IDF Diabetes Atlas. 5nd ed. Belgium: International Diabetes Federation (US), 2011: 1-135.

4. Badawi A, Klip A, Haddad P, Cole DEC, Bailo BG, El Sohemy A, et al. Type 2 diabetes mellitus and inflammation: Prospects for biomarkers of risk and nutritional intervention. Diabetes Metab Syndr Obes 2010; 26; 173-86.

5. Canadian Diabetes Association. The prevalence and costs of diabetes. 2012, Available from: http://www.diabetes.ca/.

6. Durmaz ZH, Demir AD, Ozkan T, Kılınç C, Güçkan R, Meral Tiryaki M. Does vitamin D deficiency lead to insulin resistance in obese individuals?. Biomed Res 2017; 28: 7491-7.

7. Kim HJ, Kang CK, Park H, Lee MG. Effects of vitamin D supplementation and circuit training on indices of obesity and insulin resistance in T2D and vitamin D deficient elderly women. J Exerc Nutr Biochem 2014; 18: 249-57.

8. Zuk A, Fitzpatrick T, Rosella LC. Effect of Vitamin D3 supplementation on inflammatory markers and glycemic measures among overweight or obese adults: a systematic review of randomized controlled trials. PloS One 2016 26; 11: e0154215.

9. Marmett B, Nunes RB. Resistance and Aerobic Training in the Treatment of Type 2 Diabetes Mellitus. J Diabetes Metab Disord Control 2017; 4: 00126. 
10. Gray SR, Baker G, Wright A, Fitzsimons CF, Mutrie N, Nimmo MA. The effect of a 12 week walking intervention on markers of insulin resistance and systemic inflammation. Prev Med 2009; 48: 39-44.

11. Miller EG, Sethi P, Nowson CA, Dunstan DW, Daly RM. Effects of progressive resistance training and weight loss versus weight loss alone on inflammatory and endothelial biomarkers in older adults with type 2 diabetes. Eur J Appl Physiol 2017; 117: 1669-78.

12. Libardi CA, De Souza GV, Cavaglieri CR, Madruga VA, Chacon-Mikahil MP. Effect of resistance, endurance, and concurrent training on TNF- $\alpha$, IL-6, and CRP. Med Sci Sports Exerc 2012; 44: 50-6.

13. Salamat KM, Azarbayjani MA, Yusof A, Dehghan F. The response of pre-inflammatory cytokines factors to different exercises (endurance, resistance, concurrent) in overweight men. Alexandr J Med 2016; 52: 367-70.

14. Kennel KA, Drake MT, Hurley DL. Vitamin D deficiency in adults: when to test and how to treat. Mayo Clin Proc 2010; 85: 752-8.

15. Jackson AS, Pollock ML. Practical assessment of body composition. Phy Sport Med 1985; 13: 76-90.

16. Pittas AG, Lau J, Hu FB, Dawson-Hughes B. The role of vitamin D and calcium in type 2 diabetes. A systemic review and meta-analysis. J Clin Endocrinol Metab 2007; 92: 2017-29.

17. Hyppönen E, Power C. Vitamin D status and glucose homeostasis in the 1958 British birth cohort. Diabetes Care 2006; 29: 2244-6.

18. Schwalfenberg G. Vitamin D and diabetes. Can Fam Physician 2008; 54: 864-6.

19. Lee C J, Iyer G, Liu Y, Kalyani RR, Bamba ND, Ligon CB, et al. The effect of vitamin D supplementation on glucose metabolism in type 2 diabetes mellitus: A systematic review and meta-analysis of intervention studies. J Diabetes Complications 2017; 31: 1115-26.

20. Von Hurst PR, Stonehouse W, Coad J. Vitamin D supplementation reduces insulin resistance in South Asian women living in New Zealand who are insulin resistant and vitamin D deficient-a randomised, placebo-controlled trial. Br J Nutr 2010; 103: 549-55.

21. Ibañez J, Izquierdo M, Argüelles I, Forga L, Larrión JL, García-Unciti M, et al. Twiceweekly progressive resistance training decreases abdominal fat and improves insulin sensitivity in older men with type 2 diabetes. Diabetes Care 2005; 28: 662-7.

22. Holten MK, Zacho M, Gaster M, Juel C, Wojtaszewski JF, Dela F. Strength training increases insulin-mediated glucose uptake, GLUT4 content, and insulin signaling in skeletal muscle in patients with type 2 diabetes. Diabetes 2004; 53: 294-305.

23. Rice B, Janssen I, Hudson R, Ross R. Effects of aerobic or resistance exercise and/or diet on glucose tolerance and plasma insulin levels in obese men. Diabetes Care 1999; 22: 684-91.

24. Shaban N, Gawinski K, Dotzert M, Milne KJ. The effects of high intensity interval training on indices of health in type 2 diabetics. FASEB J 2011; 25: 1057-4.

25. Wamberg L, Kampmann U, Stødkilde-Jørgensen H, Rejnmark L, Pedersen SB, Richelsen B. Effects of vitamin D supplementation on body fat accumulation, inflammation, and metabolic risk factors in obese adults with low vitamin D levels - results from a randomized trial. Eur J Intern Med 2013; 24: 644-9.

26. Maestro B, Molero S, Bajo S, Davila N, Calle C. Transcriptional activation of the human insulin receptor gene by 1, 25-dihydroxyvitamin D3. Cell Biochem. Funct 2002; 20: 227-32.

27. Sertznig P, Seifert M, Tilgen W, Reichrath J. Peroxisome proliferator-activated receptor (PPAR) and vitamin D receptor (VDR) signaling pathways in melanoma cells: promising new therapeutic targets?. J Steroid Biochem Mol Biol 2010; 121: 383-6. 
28. Byyny RL, Verde ML, Lloyd S, Mitchell W, Draznin B. Cytosolic calcium and insulin resistance in elderly patients with essential hypertension. J Clin Hypertens 1992; 5: 459-64.

29. Björklund A, Lansner A, Grill VE. Glucose-induced [Ca2+] i abnormalities in human pancreatic islets: important role of overstimulation. Diabetes 2000; 49: 1840-8.

30. Chen JJ, Jin H, Ranly DM, Sodek J, Boyan BD. Altered Expression of Bone Sialoproteins in Vitamin D-Deficient rBSP2. 7 Luc Transgenic Mice. J Bone Miner Res 1999; 14: 221-9. 31. Naharci I, Bozoglu E, Kocak N, Doganci S, Doruk H, Serdar M. Effect of vitamin D on insulin sensitivity in elderly patients with impaired fasting glucose. Geriatr Gerontol Int 2012; 12: 454-60.

32. Kessler HS, Sisson SB, Short KR. The potential for high-intensity interval training to reduce cardiometabolic disease risk. Sports Med 2012; 42: 489-509. 